\title{
FINANCIAL DERIVATIVES TRADING IN CME GROUP*
}

\author{
Olja Munitlak Ivanović ${ }^{1}$ \\ Educons University, Faculty of Business Economics, Sremska Kamenica, \\ Serbia \\ Petar Mitić \\ Educons University, Faculty of Business Economics, Sremska Kamenica, \\ Serbia (PhD student at the University of Niš, Faculty of Economics)

\section{Jelena Obradović} \\ Higher School of Professional Business Studies, Novi Sad, Serbia
}

\begin{abstract}
This paper gives an overview of the current situation and trends in the CME Group as a leader in the global market of financial derivatives. Special emphasis is placed on CME Globex - the electronic trading platform within the CME Group. The methodology used in this paper is typical for social sciences: a comparative analysis, historical analysis, and analysis of data, which enabled the use of various materials from books, scholarly journals, electronic databases and official documents and reports. The first part of this paper gives an overview of financial derivatives in general. The remaining part of the paper describes CME Group - its genesis, types of trading, permitted types of trading orders, market instruments and trading volume.
\end{abstract}

Keywords: financial derivatives, CME Group, CME Globex, international trade

\section{INTRODUCTION}

Derivatives, especially financial derivatives, have been a constant target of criticism for many years. Criticism especially flared after the global financial crisis in 2008. Standpoints on financial derivatives remain divided even amongst the top financial economists. According to Iglič (2008), a tempestuous debate was conducted between Warren Buffett ${ }^{2}$ and Alan Greenspan": "Warren Buffett is of the view that derivatives are a time bomb waiting to explode, both for those dealing in them and for the economic system itself. In Warren Buffets opinion, derivatives represent financial weapons of mass destruction, those bringing along danger, albeit for the time being a latent one, but potentially and certainly, a danger that shall be lethal. Alan Greenspan stood up in defence of financial derivatives, saying that the growing deployment of complex financial derivatives does not represent a threat for the financial system of the

\footnotetext{
* This paper is a part of research projects numbers 47009 and 179015 financed by the Ministry of Science and Technological Development of the Republic of Serbia.

1 oljaivanovic@eunet.rs

${ }^{2}$ Warren Buffett is one of the most successful investors of the twentieth century. Buffett is the chairman, CEO and largest shareholder of Berkshire Hathaway.

3 Alan Greenspan is an American economist who served as Chairman of the Federal Reserve of the United States from 1987 to 2006.
}

Vol. 16, бpoj 4/2014, cmp. 153-168 
country. "Benefits from derivatives exceed by far their costs", Greenspan said on that occasion" (p. 75)

In this paper an overview of the financial derivatives was necessary to define derivatives and explain their genesis. The definition and a historical background of derivative contracts is given, and also the explanation of the benefits and risks of their usage. Second part of the paper is dedicated to CME Group which is comprised of four separate markets: Chicago Mercantile Exchange (CME), Chicago Board of Trade (CBOT), New York Mercantile Exchange (NYMEX) and Commodities Exchange (COMEX). Characteristics of each separate market and their role in CME Group are explained.

The aim of this paper is to determine whether open outcry, as a system of trading, is outdated or not. The third part of the paper is examining CME Globex electronic platform and open outcry - two specific types of trading in CME Group. Even though Globex platform has numerous benefits, open outcry is not completely replaced and both trading systems are now represented on the exchange. The first hypothesis is, therefore, defined:

H1: Trading via open outcry is a significant part of the total trading in CME Group markets.

CME Group has a diverse number of permitted types of trading orders. Price, time, quantity and other types of orders are the topic of the forth part of this paper. Furthermore, the paper aims to explore whether number of market instruments and volume of trading increases over time. The last part considers a diverse selection of market instruments and gives an overview of the trading volume. The second hypothesis is, accordingly, defined as:

$\mathrm{H} 2$ : Number of instruments and trading volume in CME Group is increasing over time.

\section{OVERVIEW OF THE FINANCIAL DERIVATIVES}

Financial market, in a broad sense, represents an organized space where supply and demand for different types of financial assets meet. An important segment of the financial market is financial derivatives market, whose volume has been constantly growing. When we discuss financial derivatives a large number of definitions in the professional literature can be found. Hull (2009) and Kolb \& Overdahl (2003), like most financial economists, agree with the definition that derivatives are a type of contract whose value depends primarily on the underlying asset, which can be a financial instrument, interest rate, foreign exchange rate or financial index. Derivatives can also have as an underlying a specific 
commodity or commodity index. Type of the underlying asset is the most important feature of a derivative instrument. Some authors on financial derivatives consider that the traditional definition of derivatives, that is based on the underlying asset, is obsolete because, for example, there is no such asset in the case of weather derivatives, electricity derivatives, etc. (Swan, 2000, p. 142). Furthermore, Hull (2009), after the abovementioned definitions, underscores that derivatives, after all, can be dependent on almost any variable.

Basic function of financial derivatives is risk management - to hedge or mitigate the risk in the underlying. Analysis shows that derivatives use is also significantly related to other important financial characteristics such as leverage, debt maturity, holdings of liquid assets, divident policy and operational hedges. (Bartram, Brown \& Fehle, 2009, p. 204)

In the modern economic environment, physical and legal entities are constantly faced with a large number of risks. To be able to operate profitably, all market operators are finding ways to avoid risks, or to diminish them in any way possible. The point is to transfer risks to those market participants who are willing to accept that risk and achieve gains/losses, as their predictions of price movements are in contrast to the predictions of those who want to protect themselves from the risks (Đorđević \& Ilić, 2012, p. 90). In the market, on one hand, we can find hedgers who want to protect themselves from risk. On the other hand, there are traders (speculators) who are willing to accept the risk because they expect gains. Grubišić, Vuković \& Branković (2012) indicate that the derivatives market has develop on the possibilities of aquiring revenue from trade and speculations. (p. 81)

When we look at the advantages and risks that derivatives bring, it is necessary to carry out their systematization. European Union Committee, in its report "The future regulation of derivatives markets: is the EU on the right track?" lists the following advantages of derivatives:

risk.

- Derivatives allow the sharing or redistribution of

- Derivatives can allow businesses to manage effectively exposures to external influences on their business over which they have no control.

- $\quad$ Parties can speculate on the values of underlying assets, without necessarily having any actual interest in the asset itself.

As for the risk that derivatives pose, the above-mentioned report emphasizes:

Vol. 16, бpoj 4/2014, cmp. 153-168 
- Lack of transparency is one of the key risk in the OTC derivatives market.

- The risk that a counterparty in a derivatives contract will not satisfy its obligations under the contract.

- Operational risks are those that occur from human error or the failure of control systems.

- $\quad$ Systemic risk describes the risk to the financial system posed by the default of a major player in the derivatives market.

Table 1.: Gross market values of over-the-counter (OTC) derivatives by risk category and instrument

\begin{tabular}{|c|r|r|r|}
\hline & Gross market values (in bn of USD) \\
\hline Risk Category / Instrument & $\mathbf{2 0 1 1}$ & $\mathbf{2 0 1 2}$ & $\mathbf{2 0 1 3}$ \\
\hline Total contracts & $\mathbf{2 7 , 2 9 7}$ & $\mathbf{2 4 , 7 3 3}$ & $\mathbf{1 8 , 6 5 8}$ \\
\hline Foreign exchange contracts & $\mathbf{2 , 5 9 2}$ & $\mathbf{2 , 3 1 3}$ & $\mathbf{2 , 2 8 4}$ \\
\hline Forwards and forex swaps & 923 & 806 & 824 \\
\hline Currency swaps & 1,324 & 1,259 & 1,186 \\
\hline Options & 345 & 249 & 273 \\
\hline Interest rate contracts & $\mathbf{2 0 , 0 0 1}$ & $\mathbf{1 8 , 8 3 3}$ & $\mathbf{1 4 , 0 3 9}$ \\
\hline Forward rate agreements & 67 & 47 & 108 \\
\hline Interest rate swaps & 18,046 & 17,080 & 12,758 \\
\hline Options & 1,888 & 1,706 & 1,174 \\
\hline Equity-linked contracts & $\mathbf{6 7 3}$ & $\mathbf{6 0 0}$ & $\mathbf{7 0 0}$ \\
\hline Forwards and swaps & 156 & 157 & 202 \\
\hline Options & 518 & 443 & 498 \\
\hline Commodity contracts & $\mathbf{4 6 6}$ & $\mathbf{3 4 7}$ & $\mathbf{2 6 4}$ \\
\hline Gold & 63 & 42 & 47 \\
\hline Other commodities & 403 & 304 & 217 \\
\hline Forwards and swaps & & & \\
\hline Options & & & \\
\hline Credit default swaps & $\mathbf{1 , 5 8 6}$ & $\mathbf{8 4 8}$ & $\mathbf{6 5 3}$ \\
\hline Single-name instruments & 958 & 527 & 369 \\
\hline Multi-name instruments & 628 & 321 & 284 \\
\hline Unallocated & $\mathbf{1 , 9 7 8}$ & $\mathbf{1 , 7 9 2}$ & $\mathbf{7 1 8}$ \\
\hline
\end{tabular}

Source: BIS Quarterly Review, September 2014. (http://www.bis.org/statistics/dt1920a.pdf)

There are many divisions of financial derivatives. Marinković (2011a) offers a division of derivatives depending on the type of an underlying asset: (i) the derivative of the exchange commodities, (ii) derivative on financial instruments and (iii) foreign currency derivatives (p. 306). Financial derivatives include four instruments: forward 
contracts, futures, options and swaps. Contracts, such as swaps and forwards, are traded on the OTC market, futures are traded only on exchanges, while the options are traded on both OTC and exchanges (Marinković, 2011a, p. 301). Table 1 provides an overview of the gross market value of various types of contracts and commodity assets.

The vast majority of financial economists, like Hull (2009), McDonald (2006) and Mishkin (2006), state that derivative instruments are from a recent date, formed in the 1970s and 1980s. The reason for this belief is that derivatives, in this period, recorded a significant growth, both in value and in volume of trading. This is corroborated by Table 2 which shows Turnovers of futures contracts traded on international exchanges, and Table 3 which shows Turnovers of options traded on international exchanges.

Table 2.: Turnovers of future contracts traded on international exchanges (numbers of contracts in millions)

\begin{tabular}{|l|c|c|c|c|}
\hline Instruments & $\mathbf{1 9 9 0}$ & $\mathbf{1 9 9 5}$ & $\mathbf{2 0 0 0}$ & $\mathbf{2 0 0 3}$ \\
\hline Interest rate & 219,1 & 561,0 & 781,2 & 1576,8 \\
\hline Currency & 29,7 & 99,6 & 43,6 & 58,7 \\
\hline Equity index & 39,4 & 114,8 & 225,2 & 725,7 \\
\hline All Markets & 288,2 & 775,4 & 1050 & 2361,2 \\
\hline
\end{tabular}

Source: Pilbeam, K. (2005) Finance and Financial Markets, p. 335

Table 3.: Turnovers of options traded on international exchanges (numbers of contracts in millions)

\begin{tabular}{|l|c|c|c|c|}
\hline Instruments & $\mathbf{1 9 9 0}$ & $\mathbf{1 9 9 5}$ & $\mathbf{2 0 0 0}$ & $\mathbf{2 0 0 3}$ \\
\hline Interest rate & 52,0 & 225,5 & 107,6 & 302,2 \\
\hline Currency & 18,9 & 23,3 & 7,1 & 14,3 \\
\hline Equity index & 119,1 & 187,3 & 481,4 & 3233,9 \\
\hline All Markets & 190,0 & 436,1 & 596,1 & 3550,4 \\
\hline
\end{tabular}

Source: Pilbeam K. (2005) Finance and Financial Markets, p. 363

Contrary to the belief that derivatives trading emerged in finance in the 1970s and 1980s, Weber (2008) states that derivative contracts emerged as soon as humans were able to make credible promises. In his discussion paper Weber (2008) also states that first derivative contracts were written in Mesopotamia in cuneiform script on clay tablets. These derivatives were contracts for future delivery of goods that were often combined with a loan. Furthermore, we can find evidence that the derivative contracts existed in ancient Greece and ancient Rome. ${ }^{4}$

\footnotetext{
${ }^{4}$ Weber (2008) cites Van De Mieroop (2005), who has given an example of a Mesopotamian derivative contract: „Thirty wooden [planks?], ten of 3.5 meters each, twenty of 4 meters each, in
} 
"Medieval Amsterdam holds the honor of the place where the first derivative on the financial assets was created. However, North America is considered to be the place where the first regulated derivatives market was established. The Chicago market was the forerunner of the entire network of modern derivatives markets in the world." (Marinković, 2011a, p. 302).

\section{A BRIEF EVOLUTION OF CME GROUP}

On a global scale CME Group is one of the largest exchanges and clearing houses for financial derivatives. Within it, the financial exchange and trade gained public character for the first time. CME Group provides adequate commercial space, financial and IT infrastructure for successful administration and trade with financial instruments, with emphasis on futures and options on futures. CME Group is comprised of four separate markets: Chicago Mercantile Exchange (CME), Chicago Board of Trade (CBOT), New York Mercantile Exchange (NYMEX) and Commodities Exchange (COMEX).

The Chicago Mercantile Exchange (CME) was established in 1898 in Chicago. Originally, CME dealt with the exchange of agricultural products. It was established as a non-profit organization named the Chicago Butter and Egg Board, which was changed in 1919 to Chicago Mercantile Exchange. Today, according to the official website of the CME Group, CME is a Designated Contract Market that offers products subject to $\mathrm{CME}$ rules and regulations. With its development $\mathrm{CME}$ significantly expanded exchange, including an increasing number of attractive products, for example: frozen pork belly futures (1961), live cattle futures (1964), futures on foreign currencies (1972), Eurodollar futures (1981) and stock index futures (1982). (http://www.cmegroup.com/company/history/timeline-of-

achievements.html, accessed on 21.09.2014.) Everette B. Harris (1970), president of CME at the time, describes innovations and changes as follows: „It became apparent that members could not continue to subsist economically on eggs alone. Necessity is the mother of invention. Beginning in the early fifties and until the present time, Exchange members have vigorously researched, tasted, and promoted many new

the month Magrattum Akshak-shemi will give to Damqanum. Before six witnesses (their names are listed). The year that the golden throne of Sin of Warhum was made." The contract was written in the nineteenth century BC. (p. 5) Weber (2008) also cites Swan (2000) who said that Athens allowed contracts for future dilivery in sea-borne trade because the city depended on the import of grain from Egypt. (p. 8) 
contracts for futures trading. Some have succeeded and some have failed, but fear of failure has not impeded progress.“ (p. 52).

First electronic futures trades were made on CME Globex electronic trading platform in 1992. Although this innovation significantly increased the efficiency of trading, the daily volume of trade agreements and the extension of trading hours, the system did not completely replace open outcry. CME in 2001 officially became the largest futures exchange. In 2002, CME became the first exchange in the United States to issue shares which are listed at the New York Stock Exchange. CME in 2007 merged with the Chicago Board of Trade, which resulted in the formation of CME Group Inc. In August 2008, the shareholders approved the merger with the New York Mercantile Exchange (NYMEX) and COMEX. The Kansas City Board of Trade (KCBT) became part of CME Group in 2012. (http://www.cmegroup.com/company/history/timeline-ofachievements.html, accessed on 21.09.2014.)

The Chicago Board of Trade (CBOT), funded in 1848, is one of the busiest commodities exchanges in the world. CBOT has more than 3,600 members, who trade almost 50 different futures and options products (Chicago Board of Trade History, Funding Universe, 2014).

The world's largest physical commodity futures exchange is The New York Mercantile Exchange (NYMEX). This exchange is also owned by the CME Group. In addition to its New York offices, it has offices in Boston, Washington, San Francisco, Dubai, London and Tokyo. The company consists of two, formerly completely separate exchanges: New York Mercantile Exchange and Commodity Exchange, Inc. (COMEX).

\section{TWO SPECIFIC TYPES OF TRADING IN CME GROUP}

In CME Group, trading with derivatives can be carried out via the CME Globex electronic platform or via the traditional system of open outcry. Futures and options exchanges worldwide are shifting from conventional open-outcry markets to electronic trading. Reasons for this shift include reduced transaction costs, fewer trading errors, and increased execution spreed (Shah \& Brorsen, 2011, p. 48).

The development and increase of global market share of CME Group is based on improving the supply of contractual arrangements and introducing new ways of trading that is based on the CME Globex electronic platform. The CME Globex platform is the first and remains among the fastest global electronic trading system for futures and options. Through its advanced functionality, high-reliability and global connectivity, it is now the world's premier marketplace for derivatives trading (,CME Globex Reference Guide“, 2014). 
Customers around the world use commercial applications to access the platform and thus they are opening a wide range of options for trading with futures and options. This enables users to access the electronic platform from anywhere around the world (facilitated market entry), insight into all market prices (increased transparency), trading in a much faster and cheaper way compared to a broker. („CME Globex Reference Guide“, 2014). This electronic trading platform offers customers:

- Streamlined development efforts,

- $\quad$ Single source for production customer support,

- Access to free risk management tools,

- More efficient access to real-time market data,

markets,

- 10-deep futures and 3-deep options for most

- High-speed, high-volume capacity,

products,

Improved options capabilities and a range of new

- Direct order routing to to Brazil Exchange BM\&FBOVESPA and Mexican Derivatives Exchange (MexDer)

- $\quad$ Access to listed products traded on, Bursa Malaysia (BMD), the Dubai Mercantile Exchange (DME), the Korean Exchange (KRX), and the Minneapolis Grain Exchange (MGEX) („CME Globex Reference Guide“, 2014).

When the aim of CME Group of achieving and securing market leadership positions and eliminating competition is considered, great emphasis is placed on improving the Globex platform. Accordingly, significant investments are made in the platform, whose efficiency and reliability are continuously increasing every year. Users can trade using Globex platform almost non-stop, from Sunday evening through Friday afternoon. For every product that is the subject of trade a separate session is determined. Products on Globex are organized as follows (Pezzutti, 2008, p. 27):

- $\quad$ Side-by-Side contracts trade for a portion of the day simultaneously via open outcry,

- Electronic-Only contracts trade only electronically,

- After-Hours Electronic contracts trade electronically after the product stops trading via open outcry.

However, despite the existence of numerous benefits of the Globex platform, the traditional open outcry is not completely replaced. 
Open outcry means trading in a pit where traders with pre-defined hand signals ${ }^{5}$ express their intentions.

Both trading systems are now represented on the exchanges, and their most significant difference is in the limit order book. In electronic trading, traders have access to an anonymous limit order book, while in open-outcry trading, no official limit order book exists (Shah \& Brorsen, 2011, p.50). Another significant difference according to Shah \& Brorsen (2011) is the state's order execution. In electronic trading, a large order can be matched with several orders from the limit order book at different prices. Therefore, large trades may have lower liquidity costs in openoutcry markets than in electronic markets (p. 50).

According to the summary of the study by Zaner Group "Open Outcry (Pit Trading) versus the Electronic GLOBEX Platform" the results are succeeding:

- Overall, $87 \%$ of all CME Group contracts are executed on Globex; $13 \%$ are executed by open outcry.

- $\quad 98 \%$ of all CME Group futures contracts are executed on Globex; $2 \%$ by open outcry.

- $22 \%$ of all CME Group options on futures are executed on Globex; $78 \%$ by open outcry.

Table 4.: Open Outcry versus the Electronic Globex Platform (February 5, 2009 vs August 10, 2010)

\begin{tabular}{|l|c|c|}
\hline & $\mathbf{2 0 0 9}$ & $\mathbf{2 0 1 0}$ \\
\hline & Globex / Open Outcry & Globex / Open Outcry \\
\hline All & $86 \% / 14 \%$ & $87 \% / 13 \%$ \\
\hline Futures only & $96 \% / 4 \%$ & $98 \% / 2 \%$ \\
\hline Options on futures only & $16 \% / 85 \%$ & $22 \% / 78 \%$ \\
\hline
\end{tabular}

Source: Zaner Group, A study in platform volume: Open Outcry (Pit Trading) versus the Electronic GLOBEX Platform, September 2010. (http://www.zaner.com/pdf/trading_volume_study.pdf)

Table 4 shows that despite many benefits and increased trading volume trough Globex Platform, traditional Open Outcry is not completely replaced. When it comes to futures, trading is achieved mostly electronically (96\% - in 2009, and $98 \%$ - in 2010). When trading with options on futures is considered, in most cases is conducted by Open Outcry, although this trend is decreasing (85\% - in 2009, and 78\% -

\footnotetext{
${ }^{5}$ A trader who is buying will have their palms facing inward, and a trader who is selling will have their palms facing outward, away from their body. Additionally, signaling in front of and away from the body indicates prace, while signaling near the face indicates quantity. (http://www.cmegroup.com/education/open-outcry-futures-trading-handsignals.html, accessed on 19.09.2014.)
} 
2010). Even though this trend is decreasing, we accept the first hypothesis - H1, because open outcry is still a significant part of trading in CME Group.

\section{PERMITTED TYPES OF TRADING ORDERS}

From the temporal aspect trade on the exchange consists of: opening times, free trade and closing time. At the time of opening and closing the orders are entered in an order book, but the transactions are not executed. In this period the equilibrium price (reference price) is determined. This price is changed after each receipt or withdrawal of a new order.

Execution of orders during free trade is achieved by matching the orders with the orders on the opposite side. When the order is delivered, if there is no order on the opposite side that meets the requirements for the realization, it is held in the order book where orders are ranked according to the time of placing as priority criteria. Within the CME Group trading session and all its elements are determined for each product separately.

We do not conclude who holds a leadership position at the global derivatives market only on the basis of the relative share in trading volume. Level of development of the trading procedures needs to be taken into account as well. CME Globex electronic platform offers one of the most advanced model in terms of the allowed types of orders. The types of orders are: Market Order, Limit Order, Price Level Order, Stop Order, Fill and Kill, Fill or Kill, Immediate or Cancel, Minimum Accepted Quantity, Day order, Good till Cancel, Good till Date, Hidden Quantity, Requested for Cross (Marinković, 2011b, p. 17-18.)

According to Marinković (2011b) Market Order and Limit Order are the most important types of accounts when it comes to pricing. Day Order, Good till Date and Good till Cancel are instructions which define the time when the order must be made, when execution stops, or a time period in which obligation of execution is valid. Fill and Kill, Fill or Kill, Immediate or Cancel and Minimum Quantity Accepted are quantity instructions. Hidden Quantity is the order in which the other participants were not able to see the total quantity in the account. Requested for Cross is a request for cross execution of transactions, which is mostly used by brokers who intend to pair the buying and selling accounts of their clients, if conditions permit (p. 18-22). 


\section{MARKET INSTRUMENTS AND TRADING VOLUME}

According to the official website of the CME Group, a wide range of traded products appear on the exchanges, which can be classified into the following groups: futures and options based on interest rates, equity indexes, foreign exchange, energy, agricultural commodities, metals, weather and real estate. According to "CME Market Reference Guide" (2010) the most important products are:

- Commodity Futures, Options And Swaps

- Energy Futures And Options

- Equity Futures And Options

- FX Futures And Options

- Interest rates Futures And Options

- Metals Futures And Options

- Weather Futures And Options

Data provided by the official website of CME Group, that gives us an overview of its' grandiosity, shows that in September 2013 volume averaged 13.1 million contracts per day, up 10 percent compared with September 2012. For the sake of comparison, in December 2010 volume averaged 10.5 million contracts per day, up 15 percent from December 2009. Total volume for December 2010 was 232 million contracts, of which 83 percent was traded electronically. Total volume for September 2013 was more than 261 million contracts, of which 84 percent was traded electronically. We can conclude that the total volume of trading in CME Group is constantly on the rise for the vast majority of instruments. ${ }^{6}$

Based on Table 5 it is evident that, for this period, the largest volume of transactions is recorded by trading with interest rates. The highest turnover was achieved in the first quarter of 2013. After trading with interest rates, according to the criterion of the size of the volume of transactions, trading with equities and energy follow, respectively, while the lowest volume is in the trading with metals.

\footnotetext{
${ }^{6}$ For example, in December 2010 CME Group interest rate volume averaged 5.0 million contracts per day. In September 2013 interest rate volume averaged 6.6 million contracts per day. In December 2010 equity index volume averaged 2.7 million contracts per day, and in September 2013 it averaged 2.9 million contracts per day. In December 2010 energy volume averaged 1.5 million contracts per day, and in September 2013 energy volume averaged 1.6 million contracts per day. (http://investor.cmegroup.com/investor-relations/releasedetail.cfm?ReleaseID=456579; http://investor.cmegroup.com/investor-relations/releasedetail.cfm?ReleaseID=794410, accessed on 22.09.2014.)
} 
Table 5.: Statistical data on trade within the CME Group in 2012 and the first quarter of 2013

\begin{tabular}{|c|c|c|c|c|c|}
\hline \multicolumn{6}{|c|}{ Quarterly Average Daily Volume (ADV) } \\
\hline \multicolumn{6}{|c|}{ CME Group ADV (in thousands) } \\
\hline Product Line: & $1 \mathrm{Q2012}$ & $2 Q 2012$ & $3 Q 2012$ & 4Q2012 & $1 \mathrm{Q2013}$ \\
\hline Interest rates & 5,613 & 5,136 & 4,514 & 4,094 & 5,656 \\
\hline Equities & 2,390 & 2,919 & 2,391 & 2,532 & 2,608 \\
\hline Foreign exchange & 846 & 920 & 846 & 767 & 1,010 \\
\hline Energy & 1,952 & 1,741 & 1,590 & 1,489 & 1,730 \\
\hline Agricultural commodities & 1,122 & 1,228 & 1,171 & 982 & 1,084 \\
\hline Metals & 385 & 372 & 327 & 324 & 396 \\
\hline Total & 12,308 & 12,376 & $\mathbf{1 0 , 8 3 9}$ & 10,188 & 12,484 \\
\hline
\end{tabular}

Source: CME Group Inc. Reports Solid First - Quarter 2013 Financial Results, World Federation of Exchanges, retrieved from: http://www.world-exchanges.org/newsviews/cme-group-inc-reports-solid-first-quarter-2013-financial-results, accessed on: 22.09.2014.

After presenting quantitive (and qualitative) data in this section, we accept the second hypothesis - $\mathrm{H} 2$, that number of instruments and trading volume in CME Group is increasing over time.

\section{CONCLUSION}

Derivative contracts were present since ancient civilizations. In general, we can define derivatives as a type of contract whose value depends primarily on the underlying asset. The extensive development of financial derivatives took place in the last thirty years of the twentieth century. Financial derivatives are used to hedge or mitigate the risk in the underlying. That is one of the main reason why they have been so popular in the previous period, and why they have been growing in value and volume.

Within the financial derivatives markets, CME Group has occupied a leading position through continuous improvement of commercial space and following the latest trends in the financial and IT infrastructure for administration and trade with financial instruments. In addition, in order to maintain this position, a large emphasis is placed on strategic initiatives in order to increase liquidity, efficiency and contract volume.

CME Group consists of four separate markets defined as a designated contract markets, which offer the widest range of global benchmark products across all major asset classes, including futures and options base on interest rates, equity indexes, foreign exchange, energy, agricultural commodities, metals, weather and real estate (http://www.cmegroup.com/company/history/, accessed on 23.09.2014.). 
Users have two options of trading with derivatives: via the CME Globex electronic platform or via the traditional system of open outcry, which is still an option, despite many advantages of electronic trading. As presented in this work, $86 \%$ of total trade in 2009 was through the CME Globex electronic platform, while $14 \%$ were realized through open outcry. This ratio in 2010 was $87 \% / 13 \%$ respectively. However, although there is a tendency of growth of electronic trading, we accept the H1 that trading via open outcry continues to be a significant part of the market, especially when options on futures are considered. Thus, despite many technological innovations and the crucial role of CME Globex electronic platform in increasing the volume and quality of the process of derivatives trading, open outcry will not be discarded for many years due to its characteristics and advantages for a specific forms of trade.

In addition to numerous other features, CME Globex offers different trading orders that provide customers around the world a wide range of trading options. With this advantage, CME Group attracts a large number of users, allowing them to customize orders to their preferences. In addition, CME Group adapted a wide range of market-based instruments. All these advantages have contributed to a continuous increasing number of CME Globex users worldwide.

CME Globex, the first and fastest global electronic trading system, allows users worldwide to access the most liquid financial derivatives market in the world. CME Group, in its approach to business, is continually working on improving the process of trading, as one of the competitive advantages of this exchange. In accordance with that, huge funds are invested in the development of CME Globex platform. Such investments enable CME Group to increase trading volume significantly and constantly. Based on the data presented in this paper, we accept $\mathrm{H} 2$ that CME Group trading volume is constantly increasing. If we consider the period from September 2012 to September 2013, volume of contracts per day increased by $10 \%$, which is yet another indicator of the continuous increase in trading volume. The largest trading volume on this market place is realized through the trading of interest rates and equities.

\section{LITERATURE}

1. Bartram, S., Brown, G., Felhe, F. (2009). International Evidence on Financial Derivatives Usage. Financial Management, 38(1), 185206.

2. BIS Quarterly Review, Retrieved from

3. http://www.bis.org/statistics/dt1920a.pdf (accessed on 18.09.2014.) 
4. CME Group (2007). CME and CBOT Complete Merger Creating the Leading Global Financial Exchange. Retrieved from

5. http://investor.cmegroup.com/investorrelations/releasedetail.cfm?ReleaseID $=254207$ (accessed on 21.09.2014)

6. CME Group (2010). Investor Relations. Retrieved from

7. http://investor.cmegroup.com/investorrelations/releasedetail.cfm?ReleaseID $=456579$ (accessed on 22.09.2014.)

8. CME Group (2010). Investor Relations. Retrieved from

9. http://investor.cmegroup.com/investorrelations/releasedetail.cfm?ReleaseID $=794410$ (accessed on 22.09.2014.)

10. CME Group (2010). Market Reference Guide, Products and services for futures, options and over-the-counter markets, Retrieved from http://www.trendfollowing.com/whitepaper/CME179_MarketRef Guide.pdf (accessed on 19.09.2014)

11. CME Group (2011). News Releases. Retrieved from

12. http://cmegroup.mediaroom.com/index.php?s=43\&item $=3088$ (accessed on 20.09.2014.)

13. CME Group (2012). Infographic: Trader's Guide to Open Outcry Hand Signals. Retrieved from

14. http://www.cmegroup.com/education/open-outcry-futures-tradinghand-signals.html (accessed on 19.09.2014.)

15. CME Group (2014). CME Globex Reference Guide, Retrieved from http://www.cmegroup.com/globex/files/GlobexRefGd.pdf (accessed on 19.09.2014.)

16. CME Group. CME. Retrieved from

17. http://www.cmegroup.com/company/cme.html (accessed on 21.09.2014.)

18. CME Group Overview. Driving Growth and Commerce. CME. Retrieved from

19. http://www.cmegroup.com/company/history/, (accessed on 23.09.2014.).

20. CME Group. Timeline of CME Achievements. Retrieved from http://www.cmegroup.com/company/history/timeline-ofachievements.html (accessed on 21.09.2014.)

21. Đorđević, B. S., \& Ilić, S. (2012). Karakteristike trgovanja opcijama i trendovi na robnim berzama. Ekonomika, 58(1), 89102. 
22. Everette, H. (1970). History of Chicago Mercantile Exchange. The Chicago Mercantile Exchange. 49-54. Retrieved from

23. http://www.farmdoc.illinois.edu/irwin/archive/books/Futrs_Tradn g_in_Livestck/Futures_Trading_in_\%20Livestock_Part\%20I_2.pd f

24. Funding Universe (2014). Chicago Board of Trade History, Retrieved from http://www.fundinguniverse.com/companyhistories/chicago-board-of-trade-history/ (accessed on 19.09.2014.)

25. Grubišić, Z., Vuković, D., \& Branković, B. (2012). Upotreba fjučersa u zaštiti na finansijskom tržištu. Ekonomika, 58(1), 80-88.

26. Hull, J. (2009) Options, Futures, and Other Derivatives. Pearson Education Inc. New Jersey.

27. Iglič, E. (2008). Finansijski derivati ante portas?. Bankarstvo, 37(9-10), 70-79.

28. Kolb, R., Overdahl, J. (2003) Financial Derivatives. John Wiley \& Sons Inc. Hoboken, New Jersey.

29. Marinković, S. (2011a) Finansijska tržišta. Ekonomski fakultet Univerziteta u Nišu. Niš

30. Marinković, S. (2011b). Mikrostruktura savremenih tržišta derivata. Ekonomske teme, (49)1, 15-30.

31. McDonald, R. (2006) Derivatives Markets. The Addison-Wesley Series in Finance. Pearson Education Inc. New Jersey.

32. Mishkin, F. (2006) The Economics of Money, Banking, and Financial Markets. The Addison-Wesley Series. Pearson Education Inc. New Jersey.

33. Pezzutti, P. (2008). Trading the US Markets, A Comperhensive Guide to US Markets for International Traders and Investors. Harriman House LTD.

34. Pilbeam, K. (2005) Finance and Financial Markets. Palgrave Macmillan. New York.

35. Report of The European Union Committee "The future regulation of derivatives markets: is the EU on the right track?" Retrieved from

http://www.publications.parliament.uk/pa/ld200910/ldselect/ldeuc om/93/9305.htm (accessed on 17.09.2014.)

36. Shah, S., \& Brorsen, W. (2011). Electronic vs. Open Outcry: Sideby-Side Trading of KCBT Wheat Futures. Journal of Agricultural and Resource Economics, 36(1), 48-62.

37. Swan, E., (2000) Building the Global Market. A 4000 Year History of Derivatives. Kluwer Law International. The Hague. 
38. Van De Mieroop, M. (2005) The Innovation of Interest: Sumerian Loans. In Goetzmann, William M. and K. Geert Rouwenhorst (eds) The Origins of Value: The Financial Innovations that Created Modern Capital Markets. Oxford University Press, Oxford.

39. Weber, J. (2008). A Short History of Derivative Security Markets. Discussion Paper 08.10. (http://dx.doi.org/10.2139/ssrn.1141689)

40. World Federation of Exchanges (2013). CME Group Inc. Reports solid first-quarter 2013 financial results, Retrieved from http://www.world-exchanges.org/news-views/cme-group-increports-solid-first-quarter-2013-financial-results

41. Zaner Group (2010). A study in platform volume: Open Outcry (Pit Trading) versus the Electronic GLOBEX Platform, Retrieved from http://www.zaner.com/pdf/trading_volume_study.pdf 